\title{
Evaluation and Empirical Analysis of Local Financial Risk
}

\author{
Peizhe Li ${ }^{1,2, a,{ }^{*}}$, Shanshan Pei ${ }^{1, b}$ \\ ${ }^{1}$ School of Business, Shan Dong University of Political science and Law, Jinan 250014, China \\ ${ }^{2}$ College of Economics and Management, Nanjing University of Aeronautics and Astronautics \\ Nanjing 210016, China \\ alipeizhe713@163.com, bpeishan616@163.com \\ ${ }^{*}$ Corresponding author
}

Keywords: Local financial risk, Evaluate, Factor analysis.

\begin{abstract}
The objective evaluation of local financial risks is of great practical significance to the prevention of local financial risks. Through the selection of financial risk index, design of local financial risk evaluation index system, build evaluation model based on the local financial risk by factor analysis method, and carry out empirical analysis of the financial risk on China's 31 provinces and autonomous regions, in order to provide basis for the prevention of local financial risk.
\end{abstract}

\section{Introduction}

In recent years, the world economy has been in a period of structural adjustment after the international financial crisis, despite the various international introduced various measures to reverse the economic weakness, but the overall recovery is currently difficult to have improved significantly, the international financial market volatility. From the domestic environment, China's economy is facing many difficulties and challenges, economy is three superimposed, structural adjustment difficulties, enterprises are facing restructuring and upgrading more difficult, the potential risks of financial institutions, with a few years ago mainly to real estate regional financial risk, has been gradually emerging. The prevention and control of regional and systematic financial risks will be the key to China's financial reform and development under the new normal state. How to guard against regional financial risks is of great significance to the stability of our country's economic development.

Markowitz (1952) presented the expected return rate of return on assets can be expected to measure, risk can be measured by the standard deviation of asset returns, and the introduction of stock market system risk and system risk of investment portfolio problem. Ross and Richard Roll (1976) put forward the arbitrage pricing theory, which expands the capital asset pricing model and studies the decision mechanism of stock price under the condition of market equilibrium. Chen Jin (2000), from the perspective of financial globalization, believes that financial globalization has increased the difficulty of financial supervision and the fragility of the banking system and brought financial risks. Fang Sheng (2009) thinks that financial risk control is based on the results of financial risk assessment, taking corresponding measures to control the possible losses caused by financial risks.

\section{The construction of the index system}

\subsection{Construction principle}

The evaluation index system of local financial risk is characterized by many variables and difficult to define the structure level. The selection and determination of indicators is the key and foundation for risk assessment. The evaluation index system should analyze the main factors that affect the local financial risk, and try to analyze it more comprehensively. The following principles should be followed to establish a scientific and reasonable financial risk evaluation index system. 
First, the principle of science. The selection of indicators should follow the objective law, which can be used for quantitative and qualitative analysis with statistical and quantitative methods. As far as possible, indicators can be quantified, and quantitative indicators should be objective and credible, which can better reflect the real situation of local financial risks.

Second, the principle of representativeness. There are many indicators that affect the local financial risk. Our evaluation model is difficult to contain all the factors, and some indicators are difficult to quantify or difficult to obtain. We can only choose the most representative indicators to reflect the basic state of local financial risks.

Third, the principle of flexibility. In order to better generate sub evaluation indicators or to combine according to different standards, it is necessary for evaluation indicators to have flexibility principle in application, and the change of indicators can be more sensitive to the changes of local financial risks.

Fourth, the principle of feasibility. The risk evaluation index of local financial institutions should not only consider the selection of scientific principles, but also consider the feasibility and operability, therefore, in the selection of indicators, as far as possible to choose the data easily available indicators, such as in the statistical yearbook or has been publicly available data, the index selection is workable and practical meaning.

\subsection{The construction of the index system}

This article mainly embarks from elements of local financial risk, combined with the characteristics of local financial industry, on the basis of relevant studies, from four aspects of local economic development index, local economic profit index, local financial liquidity indicators, local financial safety index, selecting 10 indexes to construct a comprehensive evaluation index system for local financial risk (Table 1).

Table 1. Index system for local financial risk.

\begin{tabular}{ccc}
\hline First level index & Second level index & Variable name \\
\hline Indicators for & Gross Regional Product & $X_{1}$ \\
economic & Local financial revenue & $X_{2}$ \\
development & Local financial expenditure & $X_{3}$ \\
\hline Profit and profit & Total assets contribution rate of Industrial & $X_{4}$ \\
index of economy & Enterprises above scale & \\
& Assets and liabilities rate of Industrial & $X_{5}$ \\
Enterprises above scale & $X_{6}$ \\
Financial liquidity & Deposit and loan ratio of banking financial \\
index & institutions & $X_{7}$ \\
& Ratio of insurance expenditure income & $X_{8}$ \\
\hline Financial security & Insurance absorptivity & $X_{9}$ \\
indicators & Non-performing loan rate & $X_{10}$ \\
\hline
\end{tabular}

\section{Empirical analysis}

This paper uses the factor analysis method to evaluate the financial risk status of the financial related statistics of the regions in the country in 2015 as an example. Through KMO test, the value of KMO is 0.71 , it is suitable for factor analysis.

The comprehensive evaluation model of local financial risk is as follows:

$$
f=\frac{\left(w_{1} f_{1}+w_{2} f_{2}+w_{3} f_{3}+w_{4} f_{4}\right)}{\left(w_{1}+w_{2}+w_{3}+w_{4}\right)}
$$


The higher the comprehensive score, the stronger the ability of local finance to resist risk. Among them, the positive value indicates that the ability of financial anti risk has an advantage over the average level. The negative value indicates that the ability of financial anti risk is at a disadvantage, which is below the average level. The rating and ranking of China's regional financial risk resistance ability is shown in Table 2 .

Table 2. The ranking of local financial risk in China

\begin{tabular}{|c|c|c|c|c|c|c|c|c|c|c|}
\hline Region & $\begin{array}{l}\text { Public } \\
\text { factor } 1\end{array}$ & $\begin{array}{c}\text { Rankin } \\
\mathrm{g}\end{array}$ & $\begin{array}{l}\text { Public } \\
\text { factor } 2\end{array}$ & $\begin{array}{c}\text { Rankin } \\
\mathrm{g}\end{array}$ & $\begin{array}{c}\text { Public } \\
\text { factor } 3\end{array}$ & $\begin{array}{c}\text { Rankin } \\
\mathrm{g}\end{array}$ & $\begin{array}{c}\text { Public } \\
\text { factor } 4\end{array}$ & $\begin{array}{l}\text { Rankin } \\
\mathrm{g}\end{array}$ & $\begin{array}{l}\text { Comprehensiv } \\
\text { e score }\end{array}$ & $\begin{array}{c}\text { Ranki } \\
\text { ng }\end{array}$ \\
\hline Beijing & 0.31 & 10 & 1.61 & 2 & 1. 01 & 4 & -1.13 & 29 & 0.47 & 5 \\
\hline Tianjin & -0.34 & 21 & -1.40 & 30 & 0.56 & 10 & -0.04 & 19 & -0.35 & 23 \\
\hline Hebei & -0.21 & 17 & 0.70 & 5 & -0.15 & 21 & 0.77 & 7 & 0.12 & 12 \\
\hline Shanxi & 0.19 & 11 & -0.55 & 22 & -2.74 & 31 & -2.69 & 31 & -0.87 & 30 \\
\hline Inner mongolia & -0.07 & 14 & -0.89 & 28 & -0.22 & 23 & -1.01 & 27 & -0.39 & 25 \\
\hline Liaoning & 0.48 & 7 & -0.04 & 18 & -0.77 & 27 & 0.32 & 10 & 0.14 & 11 \\
\hline Jilin & -0.43 & 22 & 0.14 & 12 & -2.07 & 30 & 1. 82 & 2 & -0.26 & 20 \\
\hline Heilongjiang & -0.23 & 18 & 0.34 & 9 & -2.06 & 29 & 1.31 & 3 & -0.20 & 19 \\
\hline Shanghai & 0.36 & 9 & 1. 12 & 3 & 0.51 & 11 & -0.70 & 25 & 0.38 & 7 \\
\hline Jiangsu & 2. 23 & 2 & 0.13 & 14 & 0.22 & 15 & -0.56 & 23 & 1.07 & 2 \\
\hline Zhejiang & 0.89 & 4 & -0.79 & 25 & -0.43 & 24 & -1.06 & 28 & 0.06 & 13 \\
\hline Anhui & 0.07 & 12 & 0.24 & 10 & -0.77 & 26 & 0.13 & 17 & -0.03 & 15 \\
\hline Fujian & -0.08 & 15 & -0.82 & 27 & 0.81 & 7 & -0.68 & 24 & -0.16 & 18 \\
\hline Jiangxi & -0.25 & 19 & 0.36 & 7 & -0.49 & 25 & 2. 35 & 1 & 0.21 & 9 \\
\hline Shandong & 1.68 & 3 & -0.11 & 19 & 0.11 & 18 & 0.80 & 5 & 0.94 & 3 \\
\hline Henan & 0.44 & 8 & 1.11 & 4 & 0.76 & 8 & 0.93 & 4 & 0.70 & 4 \\
\hline Hubei & 0.02 & 13 & 0.21 & 11 & 0.86 & 6 & 0.53 & 8 & 0.28 & 8 \\
\hline Hunan & 0.73 & 6 & 0.10 & 15 & -1.58 & 28 & -0.50 & 22 & 0.03 & 14 \\
\hline Guangdong & 2. 91 & 1 & 0.14 & 13 & 1.38 & 1 & -0.04 & 18 & 1.68 & 1 \\
\hline Guangxi & -0.09 & 16 & -0.77 & 24 & 0.38 & 12 & 0.23 & 12 & -0.09 & 16 \\
\hline Hainan & -1.19 & 29 & -0.03 & 17 & 1.09 & 2 & 0.13 & 16 & -0.38 & 24 \\
\hline Chongqing & -0.25 & 20 & -0.79 & 26 & 0.70 & 9 & 0.19 & 14 & -0.13 & 17 \\
\hline Sichuan & 0.74 & 5 & 0.35 & 8 & -0.19 & 22 & 0.24 & 11 & 0.43 & 6 \\
\hline Guizhou & -0.84 & 26 & -0.44 & 21 & 0.00 & 20 & 0.36 & 9 & -0.44 & 26 \\
\hline Yunnan & -0.52 & 23 & -0.63 & 23 & 0.37 & 13 & 0.22 & 13 & -0.28 & 21 \\
\hline Tibet & -1.83 & 31 & 3. 45 & 1 & 0.12 & 17 & -1.77 & 30 & -0.46 & 27 \\
\hline Shaanxi & -0.53 & 24 & 0.65 & 6 & 1.08 & 3 & 0.79 & 6 & 0.17 & 10 \\
\hline Gansu & -0.98 & 27 & -0.32 & 20 & 0.06 & 19 & -0.10 & 20 & -0.55 & 28 \\
\hline Qinghai & -1.40 & 30 & -1.01 & 29 & 0.35 & 14 & -0.29 & 21 & -0.86 & 29 \\
\hline Ningxia & -1.10 & 28 & -2.07 & 31 & 0.95 & 5 & -0.75 & 26 & -0.89 & 31 \\
\hline Xinjiang & -0.72 & 25 & 0.00 & 16 & 0.13 & 16 & 0.17 & 15 & -0.31 & 22 \\
\hline
\end{tabular}

On the basis of factor interpretation, combined with table 2 and relevant source data, the ranking of various regional financial risks in various public factors can be obtained.

(1) Among the economic development level factors, the top six scores are Guangdong, Jiangsu, Shandong, Zhejiang, Sichuan and Hunan. These areas are a good base for our country's economic development. It has obvious advantages in terms of Gross Regional Product, local fiscal revenue and local fiscal expenditure. The average absorption rate of insurance institutions is strong, indicating that the insurance companies in these areas are strong.

(2) Among the assets operating factors, the top six are Tibet, Beijing, Shanghai, Henan, Hebei and Shaanxi. The area has strong ability of capital operation, including Beijing, Shanghai, Henan, Hebei 
and Shaanxi. In Tibet, the ratio of assets and liabilities of industrial enterprises is low, but the ratio of insurance expenditure to insurance expenditure is high.

(3) Among the financial security factors, the top six are Guangdong, Hainan, Shaanxi, Beijing, Ningxia and Hubei. It shows that the rate of non-performing loans in these areas is low, and the loan ratio of the banking financial institutions is more reasonable.

(4) Among the asset contribution factors, the top six are Jiangxi, Jilin, Heilongjiang, Henan, Shandong and Shaanxi. It shows that the total assets contribution rate of the industrial enterprises above the scale of these areas is high, and the financial environment has been greatly improved, and the decline of non-performing loans is more obvious.

\section{Summary}

Judging from the evaluation results, the area with strong financial risk resistance in China is the Yangtze River Delta area. The risk resisting ability is weaker in inland and Northeast China, and the evaluation results are basically consistent with the fact. Although due to the special nature of the financial industry, many data are difficult to obtain, due to limitations of index selection in a certain extent, the evaluation results cannot fully reflect the regional financial risk to a certain extent, but also can reflect the basic situation of the financial risk in all regions, can provide a basis and reference for decision makers still, it has great practical significance. In actual risk prevention, financial regulators in different regions can take precautions against local financial risks according to specific circumstances, and take corresponding risk control measures in time.

\section{Acknowledgement}

This research was financially supported by the Social science planning research project of Shandong (14BGLJ07); the Research of the Theory and Practice of Ideological and Political Education of Shan Dong University of Political science and Law: Research on the application of flexible management of the education of college Students; Research on network moral education of college students; the Scientific research project of Shan Dong University of Political science and Law(2015Z03B).

\section{References}

[1] Markowitz H. Portfolio Selection [J]. Journal of Finance, 1952 (1):77-91.

[2] Ross S. The arbitrage theory of capital asset pricing [J].Journal of Economic Theory, 1976, 13(3):341-360.

[3] Chen Jin. The trend of financial globalization and financial risk control in China [J]. Finance and economy, 2000 (11): 16-18.

[4] Fang Sheng. Research on the financial risk control of supply chain in Hunan branch of China Bank of China [D]. Hunan University, 2009 (4).

[5] Mossin J. Equilibrium in a capital assetmarket [J]. Econometrica, 1966, 34(4): 768-783.

[6] Roll R. A critique of the asset pricing theory s test [J]. Journal Financial Economics, 1977, (4): 129-176.

[7] Julian Walmsley. International Money and Foreign Exchange Market: An Introduction [M]. John Wiley\& Sons, Inc, 1998.

[8] Liu Li. Financial risk and financial risk control in China's economic transition period [J]. Financial research, 1997 (7): 24-26.

[9] Black ,Fisher, Hedging, Speculation and Systemic Risk [J]. The Journal of Derivative, Vol. 2, No.4, 1995. 
[10] Harvard Business Review, Using Derivatives What Senior Managers Must Know [J]. Harvard Business Review, January, 1995. 